\title{
Stress-Induced Sensitization and Glucocorticoids. II. Sensitization of the Increase in Extracellular Dopamine Induced by Cocaine Depends on Stress-Induced Corticosterone Secretion
}

\author{
Françoise Rougé-Pont, Michela Marinelli, Michel Le Moal, Hervé Simon, and Pier Vincenzo Piazza \\ Ṕsychobiologie des Comportements Adaptatifs, INSERM U259, Université de Bordeaux II, Domaine de Carreire, \\ 33077 Bordeaux Cedex, France
}

Secretion of glucocorticoids seems to control stress-induced sensitization of the behavioral effects of drugs of abuse by acting on the mesencephalic dopaminergic transmission, the principal neural substrate of sensitization. In order to investigate the mechanisms of this interaction between glucocorticoids and dopamine, we studied the sensitization of the increase in extracellular concentration of dopamine induced by cocaine in male rats in which corticosterone secretion was either intact or blocked. Extracellular concentrations of dopamine were evaluated in the nucleus accumbens of freely moving animals by means of microdialysis. Metyrapone, an inhibitor of corticosterone synthesis, was used to block stress-induced corticosterone secretion. Food-restriction ( $90 \%$ of the initial body weight) was the stressor used to induce sensitization. It was found that metyrapone $(100 \mathrm{mg} / \mathrm{kg}$ s.c. twice a day for 8 d) suppressed stress-induced sensitization of the increase in accumbens dopamine induced by cocaine (10 $\mathrm{mg} / \mathrm{kg}$, i.p.) and sensitization of cocaine-induced locomotion. Metyrapone suppressed both the development and the expression of sensitization. Thus, sensitization was equally blocked when the metyrapone treatment started either $1 \mathrm{~d}$ before the start of food-restriction or $\mathbf{8} \mathrm{d}$ later, that is, when food-restriction-induced sensitization to cocaine was already established. In conclusion, our results suggest that glucocorticoids modify sensitization of the behavioral effects of cocaine by acting on extracellular concentrations of dopamine. Since addictive properties of psychostimulants seem mediated by the increase in extracellular concentrations of dopamine they induce, these findings may have implications for the development of new therapeutic strategies of addiction.

[Key words: glucocorticoids, stress-induced sensitization, cocaine, dopamine, nucleus accumbens, drug abuse]

Stress-induced sensitization of the motor and addictive effects of psychostimulant and opioid drugs (Kalivas and Stewart, 1991; Robinson and Berridge, 1993) seems mediated by stress-induced

\footnotetext{
Received Apr. 6, 1995; revised June 13, 1995; accepted June 21, 1995.

This work was supported by Institut National de la Santé et de la Recherche Médicale (INSERM), Université de Bordeaux II, Conseil Régional d'Aquitaine, Pôle Médicament d'Aquitaine, Ministère de la Recherche et de l'Enseignement Supérieur. We thank Martine Kharouby for precious technical help. M.M. was supported by a grant of the "Dottorato di Ricerca in Neuroscienze" University of Rome.

Correspondence should be addressed to Dr. Pier Vincenzo Piazza, INSERM U259, Rue Camille Saint-Saëns, 33077 Bordeaux Cedex, France.

Copyright (C) 1995 Society for Neuroscience 0270-6474/95/157189-07\$05.00/0
}

secretion of glucocorticoids. First, stress-induced sensitization of the motor effects of psychostimulants and opioids is suppressed by the removal of the adrenal glands (Deroche et al., 1992a, 1993a, 1994), the principal source of endogenous glucocorticoids. Second, sensitization is reinstated in stressed adrenalectomized rats by the administration of corticosterone, the principal glucocorticoid in the rodent, at doses reproducing stress levels of the hormone (Deroche et al., 1995). Third, repeated corticosterone injections, to unstressed rats, induce sensitization of the locomotor (Deroche et al., 1992b) and reinforcing effects of amphetamine (Piazza et al., 199la).

Glucocorticoids seem to control stress-induced sensitization by acting on the mesencephalic dopaminergic transmission, the principal neural substrate of sensitization (Robinson and Becker, 1986; Kalivas and Stewart, 1991; Robinson and Berridge, 1993). Thus, sensitization of the locomotor responses to either amphetamine or morphine, injected, respectively, into the nucleus accumbens or the ventral tegmental area (VTA), are abolished by the suppression of stress-induced corticosterone secretion (Deroche et al., 1995). The locomotor activation induced by the injection of psychostimulants (Kelly and Iversen, 1976; Delfs et al., 1990) and opioids (Joyce and Iversen, 1979; Kalivas et al., 1983; Vezina and Stewart, 1984) in these cerebral area depends on the mesencephalic dopaminergic transmission.

The mechanisms by which glucocorticoids control the sensitization of dopamine-dependent effects of drugs is still largely unknown. Modulation by glucocorticoids of drug-induced increases in the extracellular concentration of dopamine is a possibility: (1) an increase in extracellular dopamine mediates motor and reinforcing effects of psychostimulants and at least in part those of opioids (Fibiger and Phillips, 1988; Koob and Bloom, 1988; Wise and Rompre, 1989; Le Moal and Simon, 1991); (2) the expression of behavioral sensitization is associated with an enhancement of drug-induced increases in extracellular concentration of dopamine (Kalivas and Stewart, 1991); (3) mesencephalic dopaminergic neurons have glucocorticoid receptors (Härfstrand et al., 1986) and glucocorticoids can modify dopamine metabolism (Ho-Van-Hap et al., 1967; Versteeg et al., 1983; Rothschild et al., 1985) and extracellular concentrations of dopamine (Imperato et al., 1989; Mittleman et al., 1992).

The possible modulation by glucocorticoids of psychostimulant-induced increase in extracellular concentrations of dopamine was studied in this report. In particular, the development and the expression of stress-induced sensitization of the dopaminergic response to cocaine was compared in rats in which 
corticosterone secretion was either intact or blocked. Sensitization of cocaine-induced locomotion was also studied.

Extracellular concentrations of dopamine were measured in the nucleus accumbens of freely moving animals by means of microdialysis. Stress-induced corticosterone secretion was blocked by metyrapone [2-methyl-1,2-di(3-pyridy])-2-propanone] an inhibitor of the enzyme 11- $\beta$-hydroxylase (Jenkins et al., 1958; Chart and Sheppard, 1959). Food-restriction was used as a stressor, since the behavioral sensitization it induces (Campbell and Fibiger, 1971; Carroll et al., 1979; Carroll and Meisch, 1981; Papasava and Singer, 1985; De Vry et al., 1989) depends on both glucocorticoids and dopamine (Deroche et al., 1995).

\section{Materials and Methods}

Subjects

Male Sprague-Dawley rats (Iffa Credo, Lyon, France) weighing 280$300 \mathrm{gm}$ at the beginning of the experiments were used. Animals were individually housed with ad libitum access to food and water. A constant light-dark cycle (on 12 P.M., off 12 A.M.) was maintained in the animal house, in which temperature $\left(22^{\circ} \mathrm{C}\right)$ and humidity $(60 \%)$ were controlled.

\section{General methods}

Drugs and drug administration. Metyrapone [2-methyl-1,2-di(3-pyridyl)-2-propanone] (Sigma) was freshly dissolved in a $0.9 \% \mathrm{NaCl}$ saline solution containing $3 \%$ of Tween 80 , and was injected subcutaneously at a dose of $100 \mathrm{mg} / \mathrm{kg} / 2 \mathrm{ml}$ twice a day (at 10 A.M. and 6 P.M.) for $8 \mathrm{~d}$. Controls received, with an identical schedule, injections of vehicle solution $(0.9 \% \mathrm{NaCl}+3 \%$ Tween 80$)$. This dose and schedule of treatment was chosen because we have previously shown that, in identical conditions, this metyrapone treatment selectively blocks stress-induced corticosterone secretion (Piazza et al., 1994). Cocaine hydrochloride was dissolved in $0.9 \% \mathrm{NaCl}$ solution and was injected intraperitoneally at a dose of $10 \mathrm{mg} / \mathrm{kg} / \mathrm{ml}$.

Locomotor activity. Animals were tested for locomotor activity in a circular corridor $(10 \mathrm{~cm}$ wide and $70 \mathrm{~cm}$ in diameter). Four photoelectric cells placed at the perpendicular axes of this apparatus automatically recorded locomotion. Since it has been previously shown that locomotor response to novelty is correlated to the dopaminergic activity in the nucleus accumbens (Hooks et al., 1991b; Piazza et al., 1991b; RougéPont et al., 1993) and to the sensitivity to the psychomotor effects of drugs (Piazza et al., 1989; Hooks et al., 1991a; Deroche et al., 1993 h), we ensured a homogenous distribution of this factor throughout the different experimental groups. For this purpose, after a period of 1 week of habituation to the housing conditions, and before any other manipulation, animals were tested for their locomotor response to novelty and evenly distributed in the different experimental groups according to their activity score cumulated over the $2 \mathrm{hr}$ of testing.

Food-restriction. Animals were weighed daily and the ration of food was progressively reduced in order to bring, over $4 \mathrm{~d}$, the body weight to $90 \%$ of its initial value. Food-restricted animals were then maintained at this weight throughout the entire experiment. $90 \%$ of food-restriction has been choosen in the present report because in preliminary experiments this level of restriction has been used to test the specificity of metyrapone effects (Piazza et al., 1994; M. Marinelli, M. Le Moal, and P. V. Piazza unpublished ohservation).

Microdialysis. Rats were chronically implanted with a guide cannula (CMA/11-Carnegie Medicin Sweden) in the nucleus accumbens under sodium pentobarbital anesthesia $(50 \mathrm{mg} / \mathrm{kg}$ i.p.). The guide cannula was lowered to $2 \mathrm{~mm}$ above the location of the probe tip. The stereotaxic coordinates relative to bregma were: $\mathrm{A} / \mathrm{P}=+3.6, \mathrm{~L}=+2.0, \mathrm{~V}=$ -6.5 from the surface of the skull, with the incisor bar set at $+5.0 \mathrm{~mm}$ with a lateral angle of $6^{\circ}$ according to the stereotaxic atlas of Pellegrino et al. (1979). A recovery period of $10 \mathrm{~d}$ after surgery was given prior the start of all other manipulations. The dialysis probe (CMA/1 I, Carnegie Medicin, $2 \mathrm{~mm}$ membrane length) was inserted through the guide cannula, $48 \mathrm{hr}$ before starting the perfusion (Osborne et al., 1991a), and during this period the rat was returned to its home cage. The day of the experiment animals were transferred to the dialysis cage $(32 \times 32 \times$ $22 \mathrm{~cm}$ ), the probe connected via a dual channel swivel (Instech) to a Harvard syringe microliter pump 22 and the perfusion started immediately at a flow rate of $2 \mu \mathrm{l} / \mathrm{min}$. The perfusion fluid was a modified artificial cerebrospinal fluid ( $145 \mathrm{~mm} \mathrm{NaCl} 1.2 \mathrm{mM} \mathrm{CaCl}_{2}, 2.7 \mathrm{mM} \mathrm{KCl}$, $1 \mathrm{mM} \mathrm{MgCl}$, and $0.2 \mathrm{~mm} \mathrm{Na} \mathrm{NPO}_{4} / \mathrm{NaH}_{2} \mathrm{PO}_{4}$ buffered at $\mathrm{pH} 7.4$ ). These conditions were used because they have been described to efficiently reflect DA synaptic relcasc and to minimize the influence of any edema induced by the implantation of the probe (Moghaddam and Bunney, 1989; Osborne et al., 1991b).

Dopamine assay. Brain dialysis was performed with a fully automated on-line system. Dialysate was collected in a $40 \mu \mathrm{l}$ sample loop. Every $21 \mathrm{~min}$ the dialysate was automatically injected into the HPLC system (Rheodyne 7125) in combination with a sample/event controller (Touzart et Matignon, France). The HPLC system consisted of a Shimadzu LC-9A pump and an analytical column (Hypersil BDS-C 18, $3 \mu \mathrm{m}, 100$ $\times 4.6 \mathrm{~mm}$; Shandon, France). The mobile phase was a sodium phosphate buffer ( $75 \mathrm{mmol}$ ) containing $20 \mu \mathrm{mol}$ of EDTA, $1.5 \mathrm{mmol}$ of sodium dodecyl sulfate, $100 \mu$ l triethylamine, $15 \%$ methanol, and $13 \%$ acetonitrile, pH 5.6 delivered at a constant flow of $0.9 \mathrm{ml} / \mathrm{min}$. A Coulometric detector (Coulochem II, ESA, USA) with a 5014 High Performance Analytical Cell was used. A model 5020 guard cell was positioned before the column to oxidize at $+350 \mathrm{mV}$. The first electrode reduced at $-175 \mathrm{mV}$ and the second electrode oxidized at $175 \mathrm{mV}$ to quantify only dopamine. Signals were recorded with a D2000 Mega integrator (Merck). The retention time of dopamine was of $6.5 \mathrm{~min}$ and the detection limit of this compound during the assay was of $0.5 \mathrm{pg}$.

Experimental groups. Five identical groups of animals were used for the two experiments of this report. Four groups of rats were submitted to food-restriction, whereas the fifth group was fed ad libitum and served as control (ad libitum fed controls). Food-restricted animals were treated with either metyrapone or vehicle. Two of these groups, one treated with metyrapone, the other with vehicle, were used for the study of the development of sensitization. The other two groups were utilized for the study of the expression of sensitization. For the study on the development of sensitization, the vehicle or metyrapone treatment started one day before the beginning of food restriction. For the study on the expression of sensitization, the treatment started after $8 \mathrm{~d}$ of foodrestriction. Since the two food-restricted groups treated with vehicle did not differ for all the parameters studied, they were cumulated in all of the figures and defined as food-restricted controls. The metyrapone groups used for the study of the development and expression of sensitization were respectively named metyrapone treated before food-restriction and metyrapone treated after food-restriction.

Histology. At the end of the experiments, the animals were anesthetized with sodium pentobarbital and perfused transcardially with $50 \mathrm{ml}$ of $0.9 \% \mathrm{NaCl}$ saline solution and then with $50 \mathrm{ml}$ of $10 \%$ formalin solution. The brains were removed and stored in $10 \%$ formalin solution until verification of cannula placement. For this purpose, brains were cut on a freezing microtome (Kryostat System, Dittes-Dispuva, Germany), and the precise location of the probe determined in coronal serial sections using thionin staining. Only the animals with correctly placed implantations (probe's membrane in the medial-anterior part of the nucleus accumbens) were included in the statistical analysis.

\section{Procedures}

Experiment l: effect of stress-induced corticosterone secretion on the sensitization of the dopaminergic response to cocaine in the nucleus accumbens. Animals were divided in the five experimental groups described above. On the day of the dialysis test, animals were placed in the dialysis cage at 11 A.M. After 2 hr of habituation to this apparatus, the animals received an injection of cocaine $(10 \mathrm{mg} / \mathrm{kg}$ i.p.). Thus, rats were tested $3 \mathrm{hr}$ after the last injection of metyrapone or vehicle. Samples of dialysate were obtained from the nucleus accumbens over 20 min intervals for $2 \mathrm{hr}$ after the cocaine injection. For this experiment nine food-restricted controls (respectively $n-5$ and $n=4$ for each time condition), eight food-restricted rats treated with metyrapone $(n=$ 4 for each time condition), and seven ad libitum fed controls were used. A supplementary set of animals was tested in order to verify the effects of food-restriction and metyrapone treatments on the dopaminergic response to the injection of $0.9 \% \mathrm{NaCl}$ saline solution. For this purpose six food-restricted controls ( $n=3$ for each time condition) and six food-restricted rats treated with metyrapone ( $n=3$ for each time condition) were compared to four ad libitum fed controls.

Experiment 2: effect of stress-induced corticosterone secretion on the sensitization of the locomotor response to cocaine. For this experiment, the five experimental groups were placed in the circular corridor at 11 A.M. After a $2 \mathrm{hr}$ period of habituation, animals received an injection of either saline or cocaine. The locomotor response to the two injections 

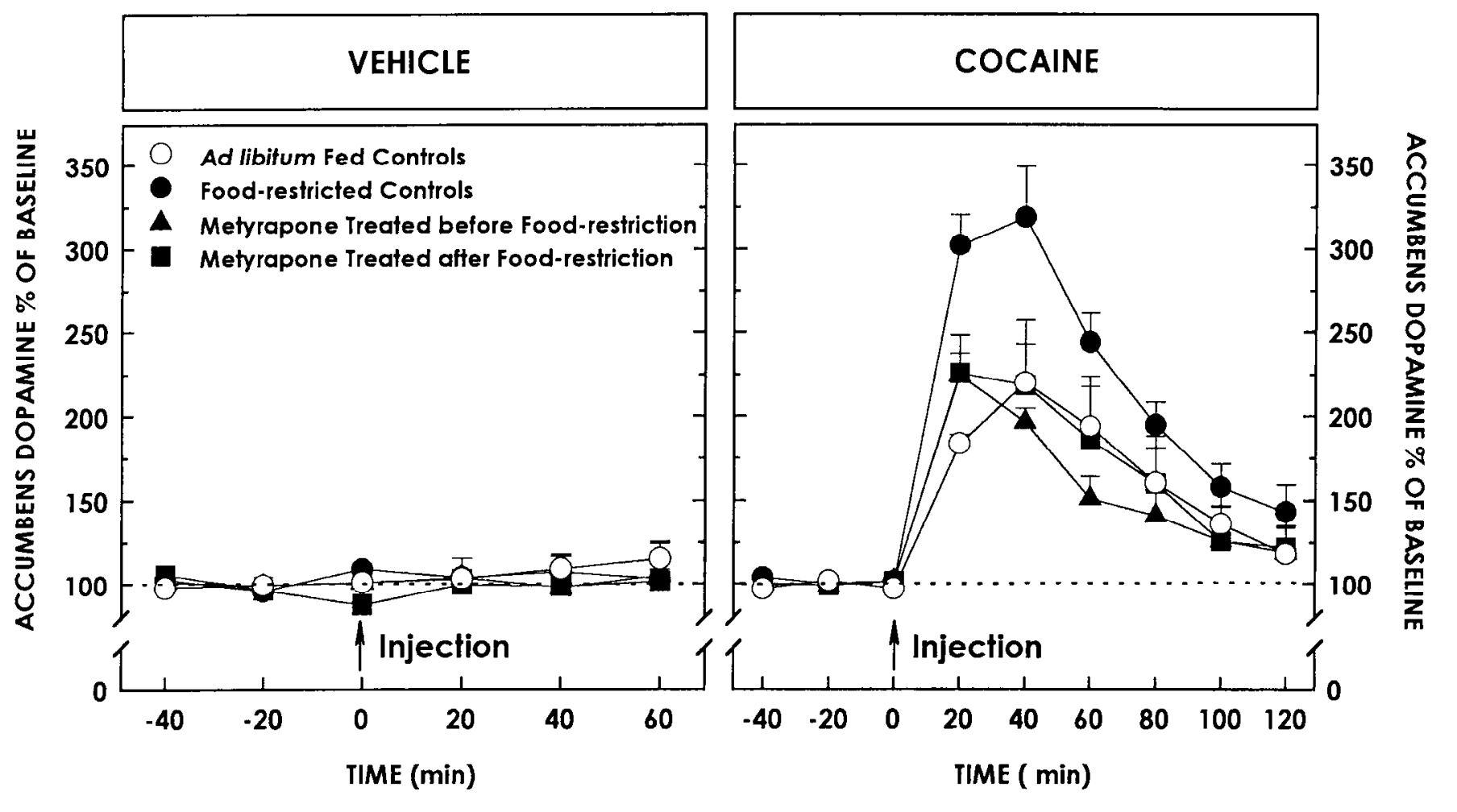

Figure 1. Extracellular concentrations of dopamine in the nucleus accumbens in response to the intraperitoneal injection of either $0.9 \% \mathrm{NaCl}$ solution (SALINE) or cocaine $(10 \mathrm{mg} / \mathrm{kg})$. The different experimental groups did not differ for their dopaminergic response to saline. In contrast, food-restricted animals pretreated with vehicle (Food-restricted Controls) showed a higher increase in extracellular concentrations of dopamine than ad libitum fed controls. This difference was significant during the first hour after the injection of cocaine $[F(2,12)=8.04, P<0.006]$. Development and expression of food-restriction-induced sensitization were suppressed by pretreatment with metyrapone. Food-restricted rats in which the treatment with metyrapone $(100 \mathrm{mg} / \mathrm{kg} \mathrm{s.c.}$, twice a day for $8 \mathrm{~d})$ started either $1 \mathrm{~d}$ before the beginning of food-restriction (Metyrapone treated before foodrestriction) or $8 \mathrm{~d}$ later (Metyrapone treated after food-restriction) had a lower response to cocaine than food-restricted animals $[F(1,13)=10.45$, $P<0.006]$ and did not differ from ad libitum fed controls.

was recorded, over $10 \mathrm{~min}$ intervals, for a period of $1 \mathrm{hr}$ after the saline injection and of $2 \mathrm{hr}$ after the cocaine injection. All the food-restricted groups contained eight subjects, whereas the ad libitum fed controls contained seven rats.

Statistical analysis. Basal extracellular dopamine concentrations, and dopamine concentrations after saline or cocaine injections (expressed as percentage of baseline), and locomotor response to saline or cocaine were compared by analysis of variance (ANOVA) for repeated measures. Newman-Keuls test was used for post hoc comparisons.

\section{Results}

Experiment 1: effect of stress-induced corticosterone secretion on the sensitization of the dopaminergic response to cocaine in the nucleus accumbens

The injection of cocaine induced a significant increase in nucleus accumbens extracellular concentrations of dopamine $[F(5,90)=$ $48.11, P<0.001]$ that was maximal $20-40 \mathrm{~min}$ after the injection. This effect was modified by food-restriction and metyrapone treatments [Treatment effect, $F(4,18)=3.31 P<0.05$ ] in a time dependent manner [Treatment $\times$ Time interaction, $F(20,90)=1.88, P<0.05]$.

Effects of food-restriction on cocaine-induced increase in dopamine. Food-restriction increased the efflux of dopamine in response to cocaine. Food-restricted groups treated with vehicle and ad libitum fed controls significantly differed $[F(2,12)=$ $4.04, P<0.05$ ] in a time dependent manner [Treatment ;ts Time interaction $F(10,60)=1.99, P<0.05]$. This difference was present during the first hour after the injection of cocaine $[F(2,12)=8.04, P<0.006]$ but not during the second one $[F(2,12)=0.80, P=0.469]$. Post hoc comparisons revealed that animals subjected to either 7 or $16 \mathrm{~d}$ of food-restriction had a higher increase in cocaine-induced dopamine efflux than ad libitum fed controls $(P<0.05$ and $P<0.01$ respectively). However the two food-restricted groups did not differ $(P=0.44)$. For this reason the two food-restricted groups treated with vehicle, in Figure 1, are cumulated as food-restricted controls.

Effects of metyrapone on cocaine-induced increase in dopamine. Metyrapone significantly reduced the enhancement of dopamine overflow observed in food-restricted animals. This effect was similar when the metyrapone treatment was started either before or after the start of food-restriction (Fig. 1, right panel). Indeed, a bifactorial analysis showed a significant effect of metyrapone $[F(1,13)=10.45, P<0.006]$ but did not reveal any interaction between this effect and the schedule of treatment $[F(1,13)=0.380, P=0.545]$. The effect of metyrapone varied over time [metyrapone $\times$ Time interaction $F(5,65)=3.28, P<$ $0.01]$ and was significant during the first hour after the injection of cocaine $[F(1,13)=14.57, P<0.002]$ but not during the second one $[F(1,13)=2.74, P=0.121]$. The treatment with metyrapone reversed the effects of food-restriction. Thus, the two groups of food-restricted rats treated with metyrapone and ad libitum fed controls did not differ $[F(2,11)=0.091, P=$ $0.911]$ neither the first $[F(2,11)=0.194, P=0.826]$ nor the second hour $[F(2,11)=0.040, P=0.955]$ following the injection of cocaine.

Effects of food-restriction and metyrapone on basal dopaminergic activity. The different experimental groups did not differ in extracellular concentration of dopamine after the injection of 


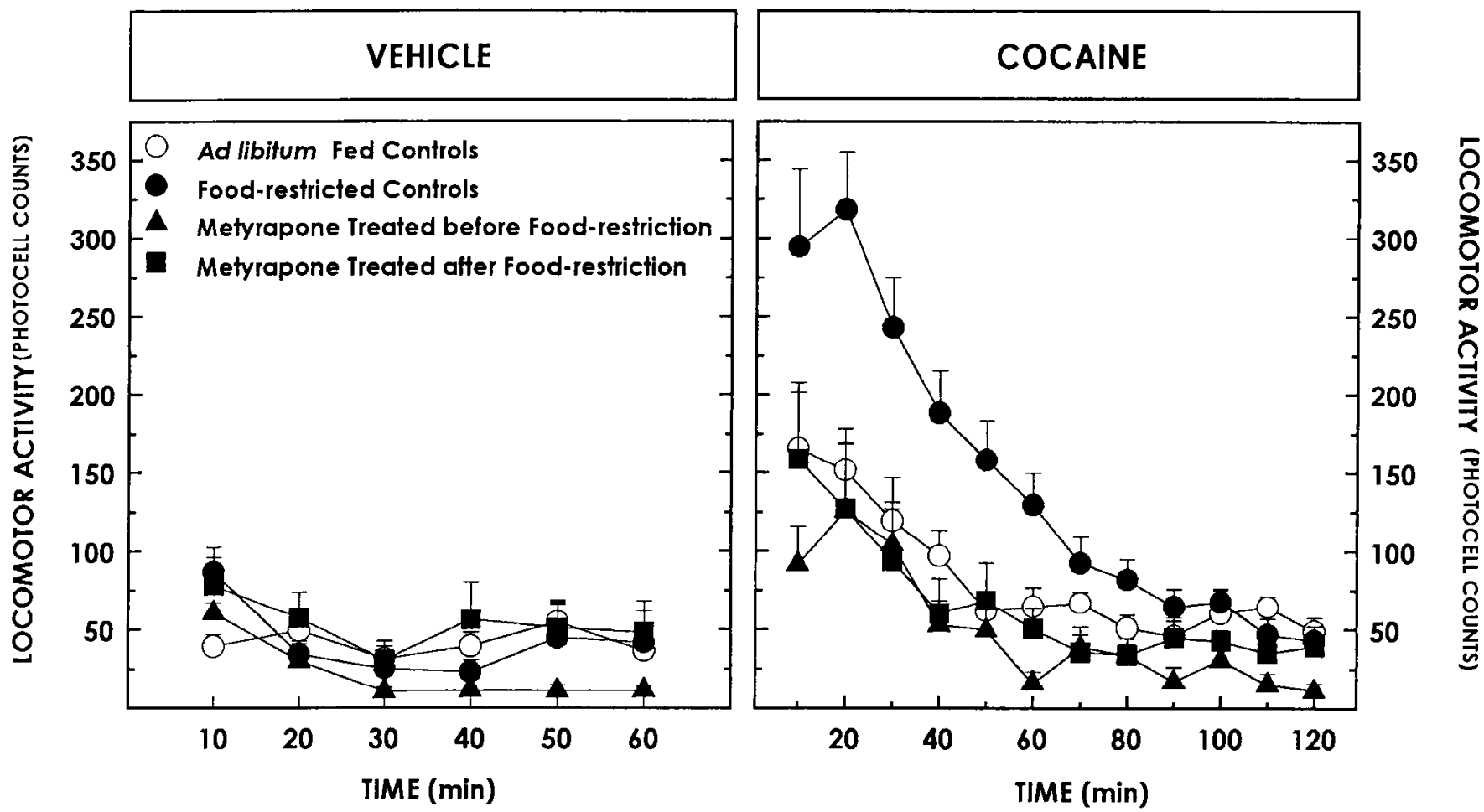

Figure 2. Locomotor response to the intraperitoneal injection of either $0.9 \% \mathrm{NaCl}$ solution (SALINE) or cocaine (10 mg/kg). The different experimental groups did not differ for their locomotor response to saline. In contrast, food-restricted animals treated with vehicle (Food-restricted Controls), showed a higher locomotor response than ad libitum fed controls. This difference was significant during the first hour after the injection of cocaine $[F(1,21)=7.13, P<0.02]$. Development and expression of food-restriction-induced sensitization were suppressed by metyrapone. Foodrestricted rats in which the treatment with metyrapone $(100 \mathrm{mg} / \mathrm{kg}$ s.c., twice a day for $8 \mathrm{~d})$ started either $1 \mathrm{~d}$ before the beginning of food-restriction (Metyrapone Treated hefore Food-restriction) or $8 \mathrm{~d}$ later (Metyrapone Treated after Food-restriction) had a lower locomotor response to cocaine than food-restricted animals $[F(1,28)=20.46, P<0.0002]$ and did not differ from ad libitum fed controls.

saline $[F(4,12)=0.318, P=0.80]$ (Fig. 1, left panel). This manipulation per se did not modify extracellular concentrations of dopamine $[F(2,22)=0.18, P=0.83]$. Furthermore, there were no group differences in baseline extracellular concentrations of dopamine $(\mathrm{pg} / 40 \mu \mathrm{l})$ the hour preceding the saline and cocaine injections $[F(2,32)=0.27, P=0.70]$. Baseline values were: ad libitum fed controls, $3.66 \pm 0.7$; food-restricted controls, $3.44 \pm 0.8$, and metyrapone-treated animals, $2.898 \pm 0.6$.

Experiment 2: effect of stress-induced corticosterone secretion on the sensitization of the locomotor response to cocaine

Food-restriction and metyrapone treatments significantly modified the locomotor response to cocaine [Treatment effect, $F(4,34)=6.39, P<0.006$ ] in a time dependent manner ['Treatment $\times$ Time interaction, $F(44,374)=2.80, P<0.001]$.

Effects of food-restriction on cocaine-induced locomotion. In parallel to what was observed for dopamine, animals subjected to 8 or $16 \mathrm{~d}$ of food-restriction did not differ $[F(1,14)=0.53$, $P=0.480]$. For this reason the two food-restricted groups are combined in Figure 2 as food-restricted controls. Food-restricted animals treated with vehicle showed a higher locomotor response to cocaine than ad libitum fed controls $[F(1,21)=5.46$, $P<0.03]$ and this difference changed over time $[F(11,231)=$ $3.5, P<0.001]$. Thus, the effect of food-restriction was present during the first $[F(1,21)=7.13, P<0.02]$ but not during the second hour $[F(1,21)=0.36, P=0.554]$ after the injection of cocaine.

Effects of metyrapone on cocaine-induced locomotion. Metyrapone significantly reduced the increase in the locomotor effects of cocaine observed in food-restricted animals. The effects of metyrapone were similar both when the treatment started before ( $1 \mathrm{~d})$ and after $(8 \mathrm{~d})$ the beginning of food-restriction. Indeed, a bifactorial analysis showed a significant effect of metyrapone $[F(1,28)=20.46, P<0.0002]$ but did not reveal any interaction between this effect and the schedule of treatment $[F(1,28)=$ $0.036, P=0.851]$. The effect of metyrapone varied over time [metyrapone $\times$ Time interaction $F(11,308)=6.70, P<0.001$ ], but was significant both during the first $[F(1,28)=19.96, P<$ $0.0002]$ and the second hour $[F(1,28)=8.85, P<0.006]$ after the injection of cocaine. Again, the metyrapone treatment reversed the effects of food-restriction. Thus, the two groups of food-restricted animals treated with metyrapone did not differ from ad libitum fed controls for the locomotor response to cocaine in total $[F(2,20)=1.79, P=0.192]$ or over time $[F(22,220)=0.52, P=0.95]$.

Effects of food-restriction and metyrapone on saline-induced changes in locomotion. The locomotor response to the injection of saline of ad libitum fed controls, food-restricted animals and metyrapone-treated rats did not differ significantly $[F(2,36)=$ $0.15, P=0.859$ ] (Fig. 2, left panel).

\section{Discussion}

The results reported here suggest that stress-induced sensitization of the dopaminergic effects of cocaine depend on corticosterone secretion. Thus, administration of metyrapone, an inhibitor of corticosterone synthesis (Jenkins et al., 1958; Chart and Sheppard, 1959), suppressed the sensitization of the cocaineinduced increase in accumbens dopamine. In parallel, metyra- 
pone also blocked the sensitization of the locomotor response to cocaine. The latest result is not surprising since an increase in extracellular concentration of dopamine in the nucleus accumbens is considered to mediate the locomotion that psychostimulants induce (Koob and Bloom, 1988; Le Moal and Simon, 1991).

Treatments with metyrapone were able to suppress both the development and the expression of stress-induced sensitization. Thus, comparable results were obtained when the metyrapone treatment started $1 \mathrm{~d}$ bcfore the start of the stress procedure (food-restriction) or $8 \mathrm{~d}$ later, that is, when the sensitization to cocaine was already established.

Our findings confirm a large body of previous literature showing that food-restriction increases locomotor (Campbell and $\mathrm{Fi}$ biger, 1971; Deroche et al., 1993a) and reinforcing (Papasava and Singer, 1985; De Vry et al., 1989) effects of psychostimulants. However, this is the first time, to our knowledge, that an enhancement by food-restriction of cocaine-induced increases in extracellular concentration of dopamine has been reported. Such a result suggests that food-restriction, similarly to other stressors, as for example foot-shock (Kalivas and Duffy, 1990) and tail pinch (Antelman et al,, 1980; Rougé-Pont et al., 1993), increases the sensitivity to psychostimulants by enhancing their effects on dopaminergic mesocorticolimbic neurons (Robinson and Becker, 1986; Kalivas and Stewart, 1991).

Several observations indicate that the effects of metyrapone on sensitization depend on an inhibition of stress-induced corticosterone secretion. Metyrapone, in conditions identical to those of this experiment, selectively blocks stress-induced corticosterone secretion without nonspecifically modifying motor or food-directed behaviors (Piazza et al., 1994). Furthermore, administration of corticosterone, at doses that raise plasma levels of the hormone in the range of those induced by stress, totally reverses the effects of metyrapone on cocaine-induced locomotion (M. Marinelli, M. Le Moal, and P. V. Piazza, unpublished observations). Finally, food-restriction-induced behavioral sensitization is also suppressed by other manipulations that block corticosterone secretion, such as adrenalectomy (Deroche et al., 1993a), and the effects of adrenalectomy are selectively reversed by the reinstatement of stress-induced corticosterone secretion (Deroche et al., 1995).

Three principal mechanisms may mediate the effects of glucocorticoids on extracellular concentrations of dopamine. First, glucocorticoids may increase dopamine synthesis by acting on tyrosine hydroxylase (TH) activity (Iuvone et al., 1977). However, effects of corticosterone on $\mathrm{TH}$ have only been demonstrated in the locus coeruleus (Markey et al., 1982) and hypothalamus (Dunn et al., 1978). Second, glucocorticoids may modify dopamine catabolism acting as reversible monoaminc oxidase (MAO) inhibitors. In rats, synthetic glucocorticoids decrease, both in vivo and in vitro, MAO activity without modifying COMT (Ho-Van-Hap et al., 1967; Caesar et al., 1970; Parvez and Parvez, 1973; Veals et al., 1977). Inhibition of MAO activity by glucocorticoids is in agreement with the changes induced by these hormones on dopamine metabolites. Thus, dexamethasone decreases deaminated products of dopamine such as HVA and dopac (Veals et al., 1977; Rothschild et al., 1985), which depend on MAO activity, whereas it increases 3MT levels that depend on COMT (Veals et al., 1977). However, no evidence exists showing that the inhibition of MAO activity may occur at physiological concentrations of glucocorticoids. Third, glucocorticoids may decrease catecholamine reuptake. This ef- fect has been shown for both noradrenaline (Iversen and Salt, 1970; Williams and Hudgins, 1973) and dopamine (Gilad et al., 1987). Inhibition of dopamine reuptake by glucocorticoids has been demonstrated in synaptosome preparations obtained from projection areas of mesencephalic dopaminergic neurons and using concentrations of the hormone that may be in the range of the physiological ones (Gilad et al., 1987).

Glucocorticoids may also control behavioral sensitization to cocaine through other neural mechanisms. For example, glucocorticoids may act at the level of postsynaptic dopaminergic re ceptors. Indeed, it has been suggested that glucocorticoids can modify the binding of dopaminergic receptors (Biron et al., 1992) and the behavioral responses to direct dopaminergic agonists (Faunt and Crocker, 1988, 1989). Furthermore, the action of glucocorticoids on behavioral sensitization may be secondary to modifications of neuronal systems other than the dopaminergic one. In particular, opioid (Chao and McEwen, 1990), GABA (Majewska et al., 1986; Majewska, 1987; Sutanto et al., 1989), excitatory amino acid (Tischler et al., 1988; Sapolsky, 1990), and 5-HT transmission (Biegon et al., 1985; De Kloet et al., 1986) are influenced by glucocorticoids and can modulate dopamine-dependent behavioral responses to psychostimulants (Scheel-Krüger et al., 1981; Kalivas et al., 1983, 1989; Kelland et al., 1990; Pulvirenti et al., 1991).

In conclusion, our results suggest that modulation of druginduced changes in extracellular concentrations of dopamine may be one of the mechanisms by which glucocorticoids control stress-induced sensitization. Since the dopaminergic effects of cocaine are considered the principal substrate of its addictive properties, our findings may have implications for the development of new therapeutical strategies of addiction.

\section{References}

Antelman SM, Eichler AJ, Black CA, Kocan D (1980) Interchangeability of stress and amphetamine in sensitization. Science 207:329331.

Biegon A, Rainbow TC, McEwen BS (1985) Corticosterone modulation of neurotransmitter receptors in rat hippocampus: a quantitative autoradiographic study. Brain Res 33:2309-2314.

Biron D, Dauphin C, Di Paolo T (1992) Effects of adrenalectomy and glucocorticoids on rat brain dopamine receptors. Neuroendocrinology 55:468-476.

Caesar PM, Collins GGS, Sandler M (1970) Catecholamine metabolism and monoamine oxidase activity in adrenalectomized rats. Biochem Pharmacol 19:921-926.

Campbell BA, Fibiger HC (1971) Potentiation of amphetamine-induced arousal by starvation. Nature 233:424-425.

Carroll ME, Meisch RA (1981) Determinants of increased drug selfadministration due to food deprivation. Psychopharmacology 74:197200.

Carroll ME, France CP, Meisch RA (1979) Food deprivation increases oral and intravenous intake in rats. Science 205:319-321.

Chao HM, McEwen BS (1990) Glucocorticoid regulation of preproenkephalin messenger ribonucleic acid in the rat striatum. Endocrinolugy 126:3124-3130.

Chart JJ, Sheppard H (1959) Amphenone analogues as adrenal cortical inhibitors. J Med Pharm Chem 1:407-411.

De Kloet ER, Sybesma H, Reul JMHM (1986) Selective control by corticosterone of serotonin 1 receptor capacity in raphe-hippocampal system. Neuroendocrinology 42:513-521.

Delfs JM, Schreiber L, Kelley AE (1990) Microinjection of cocaine into the nucleus accumbens elicits locomotor activation in the rat. $\mathrm{J}$ Neurosci 10:303-310.

Deroche V, Piazza PV, Casolini P, Maccari S, Le Moal M, Simon H (1992a) Stress-induced sensitization to amphetamine and morphine psychomotor effects depend on stress-induced corticosterone secretion. Brain Res 598:343-348.

Deroche V, Piazza PV, Maccari S, Le Moal M, Simon H (1992b) Re- 
peated corticosterone administration sensitizes the loconotor response to amphetamine. Brain Res 584:309-313.

Deroche V, Piazza PV, Casolini P, Le Moal M, Simon H (1993a) Sensitization to the psychomotor effects of amphetamine and morphine induced by food restriction depends on corticosterone secretion. Brain Res 611:352-356.

Deroche V, Piazza PV, Le Moal M, Simon H (1993b) Individual differences in the psychomotor effects of morphine are predicted by reactivity to novelty and influenced by corticosterone secretion. Brain Res 623:341-344.

Deroche V, Piazza PV, Le Moal M, Simon H (1994) Social isolationinduced enhancement of the psychomotor effects of morphine depends on corticosterone secretion. Brain Res 640:136-139.

Deroche V, Marinelli M, Maccari S, Le Moal M, Simon S, Piazza PV (1995) Stress-induced sensitization and glucocorticoids. I. Sensitization of dopamine-dependent locomotor effects of amphetamine and morphine depends on stress-induced corticosterone secretion. J Neurosci 15:7181-7188.

De Vry J, Donselaar I, Van Ree JM (1989) Food deprivation and acquisition of intravenous cocaine self administration in rats: effects of naltrexone and haloperidol. J Pharmacol Exp Ther 251:735-740.

Dunn AJ, Gildersleeve B, Gray HE (1978) Mouse brain tyrosine hydroxilase and glutamic acid decarboxylase following treatment with adrenocorticotrophic hormone, vasopressin or corticosterone. J Neurochem 31:977-982.

Faunt JE, Crocker AD (1988) Adrenocortical hormone status affects responses to dopamine receptor agonists. Eur J Pharmacol 152:255-261.

Faunt JE, Crocker AD (1989) Effects of adrenalectomy on responses mediated by dopamine D-1 and D-2 receptors. Eur. J Pharmacol 162 : 237-244

Fibiger HC, Phillips AG (1988) Mesocorticolimbic dopamine systems and reward. Ann NY Acad Sci 537:206-215

Gilad GM, Rabey JM, Gilad VH (1987) Presynaptic effects of glucocorticoids on dopaminergic and cholinergic synaptosomes. Implications for rapid endocrine-neural interactions in stress. Life Sci 40 2401-2408

Härfstrand A, Fuxe K, Cintra A, Agnati AF, Zini I, Wilkström AC, Okret S, Yu ZY, Goldstein M, Steinbuch H, Verhöfstad A, Gustafsson JA (1986) Glucocorticoid receptor immunoreactivity in monoaminergic neurons of rat brain. Proc Natl Acad Sci USA 83:9779-9783.

Ho-Van-Hap A, Babineau LM and Berlinguet L (1967) Hormonal action on monoamine oxidasc activity in rats. Can $\mathrm{J}$ Biochem $45: 355$ 361

Hooks MS, Jones GH, Neill DB, Justice JB Jr (1991a) Individual differences in amphetamine sensitization: dose dependent effects. Pharm Biochem Behav 41:203-210.

Hooks MS, Jones GH, Smith AD, Neill DB, Justice JB Jr (1991b) Response to novelty predicts the locomotor and nucleus accumbens dopamine response to cocaine. Synapse 9:121-128.

Imperato A, Puglisi-Allegra S, Casolini P, Zocchi A, Angelucci L (1989) Stress-induced enhancement of dopamine and acetylcholine release in limbic structure: role of corticosterone. Eur J Pharmaco $165: 337-339$

Iuvone PM, Morasco J, Dunn A (1977) Effect of corticosterone on the synthesis of $\left[{ }^{3} \mathrm{H}\right]$ catecholamines in the brain of $\mathrm{CD}-1$ mice. Brain Res 120:571-576.

Iversen LL, Salt PJ (1970) Inhibition of catecholamine uptake by steroids in the isolated rat heart. Br J Pharmacol 40:528-530.

Jenkins JS, Meakin JW, Nelson DH, Thorn GW (1958) Inhibition of adrenal steroid 11-oxygenation in the dog. Science 128:478-479.

Joyce EM, Iversen SD (1979) The effect of morphine applied locally to mesencephalic dopamine cell bodies on spontaneous motor activity in the rat. Neurosci Lett 14:207-212.

Kalivas PW, Duffy P (1990) Effects of acute and daily cocaine treatments on extracellular dopamine in the nucleus accumbens. Synapse $5: 48-58$.

Kalivas PW, Widerlöv E, Stanley D, Breese G, Prange AJ Jr (1983) Enkephalin action on the mesolimbic system: a dopamine-dependent and dopamine-independent increase in locomotor activity. J Pharmacol Exp Ther 227:229-237.

Kalivas PW, Duffy P, Barrow J (1989) Regulation of the mesocorticolimbic dopamine system by glutamic acid receptor subtypes. J Pharmacol Exp Ther 251:378-387.

Kalivas PW, Stewart J (1991) Dopamine transmission in the initiation and expression of drug- and stress-induced sensitization of motor activity. Brain Res Rev 16:223-244.

Kelland MD, Freeman AS, Chiodo LA (1990) Serotoninergic afferent regulation of the basic physiology and pharmacological responsive ness of nigrostriatal dopamine neurons. J Pharmacol Exp Ther 253: $803-811$.

Kelly PH, Iversen SD (1976) Selective 6-OHDA-induced destruction of mesolimbic dopamine neurons: abolition of psychostimulant-induced locomotor activity in rats. Eur J Pharmacol 40:45-56.

Koob GF, Bloom FE (1988) Cellular and molecular mechanisms of drug dependence. Science 242:715-723.

Le Moal M, Simon H (1991) Mesocorticolimbic dopamine network functional and regulatory roles. Physiol Rev 71:155-234.

Majewska MD (1987) Antagonist-type interaction of glucocorticoids with the GABA receptor-coupled chloride channel. Brain Res 418 377-382.

Majewska MD, Harrison NL, Schwartz RD, Barker II , Paıl SM (1986) Steroid hormone metabolites are barbiturate-like modulators of the GABA receptors. Science 232:1004-1007.

Markey KA, Towle AC, Sze PY (1982) Glucocorticoid influcnce on tyrosine hydroxylase activity in mouse locus coeruleus during postnatal development. Endocrinology 111:1519-1523.

Mittleman GM, Blaha CD, Phillips AG (1992) Pituitary-adrenal and dopaminergic modulation of schedule-induced polydipsia: behavioral and neurochemical evidence. Behav Neurosci 106:402-408.

Moghaddam B, Bunney BS (1989) Ionic composition of microdialysis perfusing solution alters the pharmacological responsiveness and basal outflow of striatal dopamine. J Neurochem 53:652-654.

Osborne PG, O'Connor WT, Kehr J, Ungerstedt U (1991a) In vivo characterisation of extracellular dopamine, GABA and acetylcholine from the dorsolateral striatum of awake freely moving rats by chronic microdialysis. J Neurosci Methods 37:93-I02.

Osborne PG, O'Connor WT, Ungerstedt U (1991b) Effect of varying the ionic concentration of a microdialysis perfusate on basal striatal dopamine levels in awake rats. J Neurochem 56:452-456.

Papasava M, Singer G (1985) Self-administration of low-dose cocaine by rats at reduced and recovered body weight. Psychopharmacology $85: 419-425$.

Parvez $H$, Parvez S (1973) The regulation of monoamino oxidase by adrenal cortical steroids. Acta Endocrinol 73:509-517.

Pellegrino LJ, Pellegrino AS, Cushman AJ (1979) A stereotaxic atlas of the brain. New York: Plenum.

Piazza PV, Deminière JM, Le Moal M, Simon H (1989) Factors that predict individual vulnerability to amphetamine self-administration. Science 245:1511-1513.

Piazza PV, Maccari S, Deminière JM, Le Moal M, Mormède P, Simon H (1991a) Corticosterone levels determine individual vulnerability to amphetamine self-administration. Proc Natl Acad Sci USA 88 : 2088-2092.

Piazza PV, Rougé-Pont F, Deminière JM, Kharouby M, Le Moal M, Simon H (1991b) Dopaminergic activity is reduced in the prefrontal cortex and increased in the nucleus accumbens of rats predisposed to develop amphetamine self-administration. Brain Res 567:169-174.

Piazza PV, Marinelli M, Jodogne C, Deroche V, Rougé-Pont F, Maccari S, Le Moal M, Simon H (1994) Inhibition of corticosterone synthesis by metyrapone decreases cocaine-induced locomotion and relapse of cocaine self-administration. Brain Res 658:259-264.

Pulvirenti L, Swerdlow NR, Hubner CB, Koob GF (1991) The role of limbic-accumbens-pallidal circuitry in the activating and reinforcing properties of psychostimulant drugs. In: The mesolimbic dopamine system: from motivation to action (Wilner P, Scheel-Krüger J eds), pp 131-139. Chichester: Wiley.

Robinson TE, Becker JB (1986) Enduring changes in brain and behavior produced by chronic amphetanine administration: a review and evaluation of animal models of amphetamine psychosis. Brain Res Rev 11:157-198.

Robinson TE, Berridge KC (1993) The neural basis of drug craving: an incentive sensitization theory of addiction. Brain Res Rev 18:247-291.

Rothschild AJ, Langlais PJ, Schatzberg AF, Miller MM, Saloman MS. Lerbinger JE, Cole JO, Bird E (1985) The effect of a single acute dose of dexamethasone on monoamine and metabolite levels in the rat brain. Life Sci 36:2491-2505.

Rougé-Pont F, Piazza PV, Kharouby M, Le Moal M, Simon H (1993) Higher and longer stress-induced increase in dopamine concentrations 
in the nucleus accumbens of animals predisposed to amphetamine self-administration. A microdialysis study. Brain Res 602:169-174.

Sapolsky RM (1990) Glucocorticoids, hippocampal damage and the glutamatergic synapse. Prog Brain Res 86:12-23.

Scheel-Krüger J, Magelund G, Olianas MC (1981) Role of GABA in the striatal output system: globus pallidus, nucleus endopeduncolaris, substantia nigra and nucleus subthalamicus. In: GABA and the basal ganglia (Di Chiara G, Gessa GL, eds), pp 165-186. New York: Raven. Sutanto W, Handelmann G, De Bree F, De Kloet ER (1989) Multifaceted interaction of corticosteroids with the intracellular receptors and with membrane GABA-A recptor complex in the rat brain. J Neuroendocrinol 1:243-247.

Tischler ME, Henriksen EJ, Cook PH (1988) Role of glucocorticoids in increased muscle glutamine production instarvation. Muscle Nerve 11:752-756.
Veals JW, Korduba CA, Symchowicz S (1977) Effect of dexamethasone on monamine oxidase inhibition by iproniazid in rat brain. Eur J Pharmacol 41:291-299.

Versteeg DHG, Van Zoest I, De Kloet ER (1983) Acute changes in dopamine metabolism in the medial basal hypothalamus following adrenalectomy. Experentia 40:112-114.

Vezina P, Stewart J (1984) Conditioning and place-specific sensitization of increases in activity induced by morphine in the VTA. Pharmacol Biochem Behav 20:925-934.

Williams PB, Hudgins PM (1973) Action of hydrocortisone, desoxycortisone acetate and progesterone on ${ }^{14} \mathrm{C}$-norepinephrine uptake and metabolism by rabbit aorta. Pharmacology 9:262-269.

Wise RA, Rompre PP (1989) Brain dopamine and reward. Annu Rev Psychol 40:191-225. 